\title{
Abortifacient effect of steroids from Ananas comosus and their analogues on mice
}

\author{
A. Pakrashi and B. Basak \\ Reproductive Biology Section, Indian Institute of Experimental Medicine, \\ Calcutta-700032, India
}

The juices of the unripe fruits and leaves of Ananas comosus, the common pineapple plant, have long been claimed to possess abortifacient properties in Indian medicine (Manjunath, 1948). More recently, an antifertility effect of the petroleum ether extract of the rhizome (Bhaduri, Ghosh, Bose, Moza \& Basu, 1968) and of the green fruits (Garg, Saksena, Chaudhury, 1970; Näf-Müller \& Willhalm, 1971) has been reported.

In a preliminary investigation, we observed an antifertility effect of an extract of the white parts of the leaves of the plant. We therefore undertook a follow-up study of the pure constituents, ergosterol peroxide (Compound I), $\beta$-sitosterol (Compound IIa) and 5-stigmastene-3 $\beta, 7 \alpha$-diol (Compound IIb) isolated (Pakrashi, Achari \& Majumdar, 1975) from the petroleum ether and benzene extracts of the whole leaves, and their synthetic analogues, 5-stigmastene-3 $\beta, 7 \beta$-diol

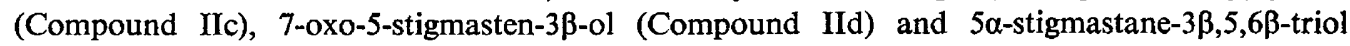
(Compound III) (see Text-fig. 1).<smiles>CCC(C)C(C)CCC(C)C1CCC2C3C(=CC4=CC(O)CCC43C)C3CCC4(C)C(CCC4C(C)C=CC(C)C(C)C)CCC3C12C</smiles><smiles>CCC(C)C(C)CCC(C)C1CCC2C3CC(O)C4(O)CC(O)CCC4(C)C3CCC12C</smiles>

Text-fig. 1. The structures of the steroids from Ananas comosus and their analogues (see text). For Compounds IIa, $\mathrm{R}=\mathrm{H}_{2} ; \mathrm{IIb}, \mathrm{R}=\mathrm{H}, \mathrm{OH}(\alpha)$; Ifc, $\mathrm{R}=\mathrm{H}, \mathrm{OH}(\beta) ; \mathrm{IId}, \mathrm{R}=\mathrm{O}$.

Colony-bred adult mice of proven fertility and weighing 22-25 g were fed a balanced diet and caged in the ratio of one male to two females in a controlled-temperature $\left(24-25^{\circ} \mathrm{C}\right)$ room. The day of finding spermatozoa in the vaginal smear was designated Day 1 of pregnancy. The test compounds (IIb and IIc as dibenzoate and IId and III as 3-benzoate) in olive oil were administered orally in a single dose of $30 \mathrm{mg} / \mathrm{kg}$ body weight on Day 1 or Days 6-7 of pregnancy. Control animals were treated with olive oil. A preliminary trial with different doses of Compound IIb had shown that $30 \mathrm{mg} / \mathrm{kg}$ body weight was the minimum effective dose for this compound, and this dose level was therefore used for the other compounds of which only small amounts were available. Laparotomy 
was performed under ether anaesthesia for all animals between Days 6-7 and Days 8-16 of pregnancy, i.e. before and after implantation when changes of vagina and mammary gland indicated that pregnancy had been disrupted.

The results in Table 1 showed that all the compounds exerted some degree of abortifacient activity when administered on Day 1 , but $\beta$-sitosterol (Compound IIa) and the 7-oxo derivative (Compound IId) were devoid of activity when given on Days 6-7.

Table 1. Abortifacient effect of steroids from Ananas comosus and their analogues on mice when administered orally before and after implantation at a dose of $30 \mathrm{mg} / \mathrm{kg}$ body weight

\begin{tabular}{|c|c|c|c|c|}
\hline \multirow[b]{2}{*}{ Treatment } & \multicolumn{2}{|c|}{ Preimplantation } & \multicolumn{2}{|c|}{ Postimplantation } \\
\hline & $\begin{array}{l}\text { No. of } \\
\text { mice used }\end{array}$ & $\begin{array}{c}\text { No. with } \\
\text { degenerating } \\
\text { or no i.s. }(\%)\end{array}$ & $\begin{array}{l}\text { No. of } \\
\text { mice used }\end{array}$ & $\begin{array}{c}\text { No. with } \\
\text { no i.s. }(\%)\end{array}$ \\
\hline None (controls) & 10 & $0(0)$ & 10 & $0(0)$ \\
\hline Ergosterol peroxide (I) & 10 & $10(100)$ & 8 & $8(100)^{*}$ \\
\hline$\beta$-Sitosterol (IIa) & 15 & $14(93 \cdot 3)$ & 11 & $0(0)$ \\
\hline 5-Stigmastene-3 $\beta, 7 \alpha$-diol (IIb) & 10 & $9(90)$ & 13 & $12(92)$ \\
\hline 5-Stigmastene-3 $\beta-7 \beta$-diol (IIc) dibenzoate & 15 & $14(93 \cdot 3)$ & 12 & $9(75)$ \\
\hline 7-Oxo-5-stigmasten-3 $\beta$-ol (IId) benzoate & 15 & $10(66 \cdot 6)$ & 10 & $0(0)$ \\
\hline $5 \alpha$-Stigmastane-3 $\beta, 5,6 \beta$-triol (III) 3-monobenzoate & 25 & $22(88)$ & 20 & $19(95)$ \\
\hline
\end{tabular}

i.s.=implantation site.

* Abortion occurred at a very late stage of pregnancy.

Ergosterol peroxide (Compound I) showed the maximum abortifacient effect at both stages of pregnancy, but the action was delayed (starting from Days 13-16), especially when given after implantation. Loss of weight, lethargy and anaemia of the treated animals were observed. Delayed action (from Days 10-16) and similar side effects were also observed with $\beta$-sitosterol (Compound IIa). The most consistent results before and after implantation and without apparent side effects were shown by Compound IIb and Compound III followed by Compound IIc. Laparotomy revealed either the absence of or disruption of implantation sites between Days 6-7 when these compounds were administered on Day 1, and on Days 9-11, 8-10 and 10-11, respectively, when they were given on Days 6-7.

We are grateful to Dr B. Achari of the Department of Medicinal Chemistry for making the compounds available to us. We also thank Professor R. N. Chakravarti, Director of the Institute, for encouragement.

\section{References}

Bhaduri, B., Ghosh, C.R., Bose, A.N., Moza, B.K. \& BASU, U.P. (1968) Antifertility activity of some medicinal plants. Indian $J$, exp. Biol. 6, 252253.

Garg, S.K., Saksena, S.K. \& Chaudhury, R.R. (1970) Antifertility screening of plants. Part VI. Effect of five indigenous plants on early pregnancy in Albino rats. Indian J. med. Res. 58, 1285-1289.

Manjunath, B.L. (1948) The wealth of India-raw materials. Council of Scientific and Industrial Research, New Delhi 1, 75-77.

NÄF-Müllek, R. \& Willhalm, B. (1971) Uber die fluchtigen Anteile der Ananas. Helv. chim. Acta 54, 1880-1890.

Pakrashi, S.C., Achari, B. \& Majumdar, P.C. (1975) Studies on Indian medicinal plants. Part XXXII. Constituents of Ananas comosus (Linn), Merr. leaves. Indian J. Chem. 13, 755-756. 